\title{
Breast cancer grant policy comes under fire
}

Washington. Two scientists from Yale University in New Haven, Connecticut, are complaining that they have been denied funding by a huge federally funded breast cancer research programme, even though they received impressively high scores when ranked by scientific peer-review panels.

Their complaints have rekindled a fierce dispute that took place when the Breast Cancer Research Program (BCRP) was set up by Congress in 1993, after intense lobbying by advocates of breast cancer research; the dispute centres on the extent to which peer-review judgements might become subservient to other factors in allocating research grants (see Nature 363, 195; 1993).

Proposals from Barry Kacinski, a radiation oncologist and tumour biologist at Yale University School of Medicine, and Trevor Williams, an assistant professor of biology at Yale University, were placed in the 98th and 90 th percentiles respectively. But they were rejected in June on the basis of decisions by a second, non-peer-review panel.

Williams' $\$ 860,000$ proposal sought to find the relevance of a particular gene to breast cancer and breast development. Kacinski's \$699,000 proposal aimed at developing a non-toxic therapy for advanced breast cancer, based on the role of glucocorticoids in invasion and metastases.

Scientific reviewers described Kacinski's proposal as "extremely well crafted" and "highly relevant to breast cancer research". One called the work "an understudied area that may have a good deal of clinical relevance, especially for patient prognosis".

But although the second 'integration' panel incorporated the scientific review scores in its judgements, it did not rely on them exclusively, adding additional criteria such as the need to avoid redundancy and to support previously underfunded areas

The manager of the programme, Alan Epstein, wrote last month to Kacinski, whose percentile score was 98.1 , that his proposal was "scientifically superb". But he said that this score was only one of many criteria used to assess a proposal.

Indeed, Epstein told Kacinski that 50 per cent of proposals ranked by the scientific peer-review panels as "outstanding" (a score between a perfect 1.0 and 1.5) or "excellent" (a score between 1.5 to 2.0) are not being funded in the current round, for which final decisions will be made before 30 September. Kacinski scored 1.2; Williams scored 1.4. An earlier, unsigned draft of Epstein's letter to Kacinski stated that the average score of a funded grant is 1.6

Williams wrote in a letter to Representative Rosa DeLauro (Democrat, Connecticut), that the process is "a systematic and wanton abuse of public funding," and that those who petitioned Congress on behalf of women's health issues "are being cheated".
The programme received $\$ 210$ million in 1993 , and at $\$ 150$ million during 1995 , the year in dispute. Action by Congress in 1990 forbidding transfers of Defense Department money to domestic budgets prevented the programme being placed in the National Cancer Institute, as its supporters had intended. Instead, it was given to the Army's medical research and material command.

Epstein argues that confidentiality prevents him from commenting on the two proposals under dispute. But he defends the process in general, saying that as more than 2,200 applications were received for about 300 grants, many of the best proposals could not be funded. "Even in that upper tier of outstanding proposals, it was incredibly competitive," he said, calling the scientists' criticisms "unsubstantiated opinion".

Epstein adds that the 24-member integration panel was asked explicitly to shape the direction of funding by considering strategic goals, with authority to reject an application - however strong the science - if it did not meet other goals that included relevance to breast cancer and the potential of resulting in a breakthrough.

Kacinski and Williams complain that the Army is secretive about these other goals. Epstein has told Kacinski that the proceedings of the integration panel in judging his proposal were not recorded, and, in any event, not for public release.

Colonel Irene Rich, the programme's director, said that in future, applicants will receive written records of reviews by the integration panel of their proposals.

But Sara Rockwell, the director of the office of scientific affairs at Yale's School of
Medicine, says that the office will in future advise investigators applying to the BCRP to hedge their bets by applying to other agencies simultaneously. "There appear to be other factors [than scientific merit] of importance here, and we don't know what they are," she says.

Defenders of the programme argue that the integration panel acted precisely as proposed in a report by the Institute of Medicine in 1993. This stated that the fundamental criterion for a successful proposal should be scientific merit, and that "second-rate research should not be supported simply on the grounds of relevance to programmatic goals". But the report also advised that a 'programmatic' review should address goals such as encouraging women and minorities to apply for grants; supporting promising but underfunded research areas; bringing new investigators into the field; and encouraging cross-disciplinary projects.

"We are trying to open up the system and open up the structure," said Fran Visco, a member of the integration panel who is also president of the National Breast Cancer Coalition and a prime mover behind the BCRP. "What this programme is able to do, which many other programmes are not, is a very thorough, programmatic review that makes certain that, regardless of scientific merit, programmatic merit also exists."

Visco said she is "livid" and that it is "appalling" that the scientists are complaining. "They have to understand that just because they're used to getting funded, that doesn't mean they're going to continue to get funded," she says. Meredith Wadman

\section{Radar will investigate magnetic storms}

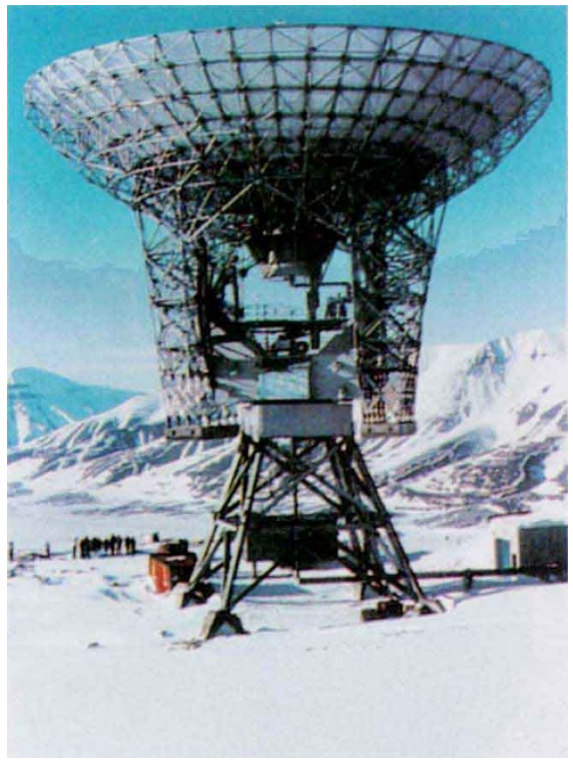

London. A radar system designed to investigate fundamental processes in the Earth's ionized upper atmosphere went on-line from the Arctic circle at the beginning of this month. The 32 metre EISCAT Svalbard Radar (ESR, left) is sited on Svalbard, an archipelago of islands halfway between the north coast of Norway and the geographic North Pole. It will investigate the chain of interactions that allow eruptions on the surface of the Sun to disturb the Earth's magnetic field and ionosphere.

These 'magnetic storms' are understood to be capable of disturbing power distribution networks, global positioning systems, radars and satellites. EISCAT is an international research organization involving seven countries - Finland, France, Germany, Norway, Sweden, the United Kingdom and Japan. 